\title{
IMPLEMENTATION ON STIMULATION, DETECTION, AND EARLY INTERVENTION OF CHILD GROWTH AND DEVELOPMENT (SDIDTK) PROGRAM IN PUSKESMAS MOJO, SURABAYA STILL EMPHASIZE ON GROWTH SCREENING
}

\author{
Dwi Susanti, Florentina Sustini \\ Department of Publich Health and Preventive Medicine \\ Faculty of Medicine, Universitas Airlangga, Surabaya
}

\begin{abstract}
ABSTRAK
Skrining perkembangan penting dilakukan agar kasus keterlambatan perkembangan anak bisa dideteksi dan ditangani sedini mungkin. Program skrining perkembangan di Puskesmas selama ini dilakukan terintegrasi dengan kegiatan skrining pertumbuhan dalam program SDIDTK (Stimulasi, Deteksi, dan Intervensi Dini Tumbuh Kembang). Penelitian ini bertujuan untuk menggali informasi tentang pelaksanaan program skrining perkembangan anak yang sudah dilakukan di Puskesmas Mojo.Desain penelitian ini adalah cross sectional dengan pendekatan metode kualitatif. Data primer diambil dari narasumber (ibu balita, ibu cadres, guru PAUD, petugas kesehatan), dan data sekunder berasal dari laporan PWS KIA di Puskesmas Mojo. Laporan hasil kegiatan SDIDTK Puskesmas Mojo mencapai 88,1\% pada tahun 2013, dan 95,2\% pada tahun 2014. Kegiatan skrining perkembangan jarang dilakukan di posyandu. Kegiatan yang rutin dilakukan di posyandu adalah skrining pertumbuhan. Kegiatan skrining perkembangan dilakukan dengan mendatangi sekolah PAUD 6 bulan sekali tetapi pemeriksaan perkembangan tidak dilakukan pada semua balita karena keterbatasan jumlah alat peraga dan tenaga kesehatan. Hasil kegiatan program SDIDTK di Puskesmas Mojo hanya mewakili kegiatan skrining pertumbuhan. (FMI 2016;52:51-56)
\end{abstract}

Kata kunci: Evaluasi, Skrining, Perkembangan anak, SDIDTK, Puskesmas Mojo

\begin{abstract}
It's Important to conduct child development screening regularly in primary health services, so child developmental delay cases can be detected and treated as early as possible. Child development screening program in Puskesmas should been carried out integrated with growth screening in Stimulation, Detection, and Early Intervention of Child Growth and Development (SDIDTK) Program. Aims of this study was to gathering informations about the implementation of child development screening activity conducted by Puskesmas Mojo. This was a cross sectional study with kualitatif method. Primary data taken from under 5 years old child's mothers, kindergarten teachers, cadres, and health staff of Puskesmas Mojo. Secondary data gotten from PWS KIA report of Puskesmas Mojo.Results of SDIDTK activities in Puskesmas Mojo according to PWS KIA report, achieve 88.1\% in 2013 and $95.2 \%$ in 2014. Child development screening activities done infrequenly in Posyandu. Routine activities of Posyandu was growth/nutrition screening. Child development screening activities done by visiting kindergarten school every 6 month but not every child getting development screen, only those who suspicious have developmental delay because of minimum number of staff and aids. Results of SDIDTK activities in Puskesmas Mojo only represents child growth screening activities. (FMI 2016;52:51-56)
\end{abstract}

Keywords: Evaluation, Screening, Child Development, SDIDTK, Puskesmas Mojo

Correspondence: Dwi Susanti, Department of Publich Health and Preventive Medicine, Faculty of Medicine, Universitas Airlangga, Surabaya

\section{INTRODUCTION}

Age of the children (0-5 years) is the golden age in the process stages of child development. At this time the development of brain structures sensitive to the experience/stimulation. If the stimulation performed optimally in that time span, the development will happen as they should, but when stimulation is given less or no interference from the environment may lead to a bottleneck in the process of further developments (Robson 2002). Council on Children With Disabilities (2006) recommends implementation of developmental screening on every child who visits the health-care activity for healthy children (every well-child preventive care visit). In Indonesia, we have posyandu. If every child that comes into posyandu can be checked also its development, it would developmental disorders can be detected as early as possible. Activities early detection of developmental delay children is very important that cases of developmental delay in children can intervene early so that the intervention be more optimal.

Research by Suwarba et al (2008) states that the average age of first discovered experiencing Global Development Delay (KPG) in Cipto Mangunkusumo is about 21.8 months. Approximately $26.6 \%$ of developmental 
delay in Speciality Clinic Developmental RSAB Harapan Kita detected in those aged $>36$ months (Tjandrajani et al 2012). This means that most parents are aware of a developmental delay late in children must be addressed too late. Lack of parental knowledge and Posyandu cadre of stages of child development causes them less vigilant in case of developmental delay in children.

Activity screening (early detection delay) the development of children in Indonesia have been carried out are integrated with the growth screening program SDIDTK (Stimulation, Detection and Early Intervention Growth) at the health center. This study aims to dig information about the implementation of screening programs, child development has been done in Puskesmas Mojo.

\section{MATERIALS AND METHODS}

This study design was cross sectional descriptive narrative approach qualitative method. Flow study began by taking secondary data on service coverage SDIDTK in the last 2 years from report PWS KIA Puskesmas Mojo, Surabaya. Then proceed with the collection of primary data from several sources. Resource persons from this study are the toddler's mother, cadre posyandu, early childhood teachers, and health workers Puskesmas Mojo. Resource mothers, Posyandu cadres and early childhood teachers interviewed with the same questions to obtain the information obtained is saturated. All three informants were obtained by approaching the cadre of regular meetings held every month.

Resource health workers obtained by inviting all midwives and dietitians in Puskesmas Mojo, 1 doctors appointed by the Head of the Health Center, and Head of Puskesmas itself to discussions with the method NGT (Nominal Group Technique) Delbeq. Discussions with NGT method Delbecq performed in 3 sessions. A discussion session was conducted in order to dig for information on how they carry out activities SDIDTK at the health center, followed by a second session discussions to identify the obstacles they face on the ground in implementing the program. Third session done to find alternative solutions to overcome the obstacles that have been discovered in the second session discussions. Some alternative solutions have been found and then selected the most likely (visible) to be done.

NGT Delbecq is one of the methods/ways of decision making developed by Van de Ven and Delbecq 1971. NGT Delbecq is a structured process that allows any member of the discussion group to freely express his ideas by writing on paper to address any issues raised by the facilitator without being influenced by other members. With this method, both members of the dominant and silent can convey his ideas. After the answers of all the members of the group write on the board, and then do an interactive discussion to confirm any answers and ideas that have been written by members of the discussion group. The answer is almost the same into one then selected again by the group members by means of writing on paper. The top answer chosen later confirmed to members of the discussion group to serve as a priority problem to be solved or the solutions that will be used.

\section{RESULTS}

\section{Toddler SDIDTK service coverage based on the report of PWS KIA Puskesmas Mojo}

Based Monitoring Report Region Local (PWS) Maternal and Child Health (MCH) we got from Puskesmas Mojo, it was reported that the coverage of stimulation, Detection and Early Intervention Growth (SDITK) are performed on infants in Puskesmas Mojo cumulatively at 2013 were reached $88.10 \%$ (Figure 1a) and an increase in 2014, which reached $95.2 \%$ (Figure 1b). In the report there is no separation between growth monitoring activities which include activities weighing and measurement of height and head circumference with growth monitoring activities usually done by a screening tool KPSP (Pre-Screening Questionnaire Development).

\section{Interview to toddlers' mothers, cadres, and related early childhood teachers on toddler activity monitoring developments}

Event information from Mother Toddler, Mrs. Cadres and early childhood teachers about their experiences related to monitoring the growth and development conducted in Puskesmas Mojo done with the interview. Informant obtained by visiting the village cadres association activities. There are three villages in Puskesmas Mojo is then selected two village cadres association at random to visit. Interviews were conducted in some mothers, mothers of cadres and early childhood teachers who attended the meeting. In an interview to the informant asked mothers, mothers of cadres, and early childhood teachers on their inspection activities in the development of integrated health besides growth monitoring activities such as weighing and measuring height and head circumference were routinely conducted every month. Excerpts answers informant mothers, cadres Posyandu, and early childhood teachers can be seen in Table 1 . 


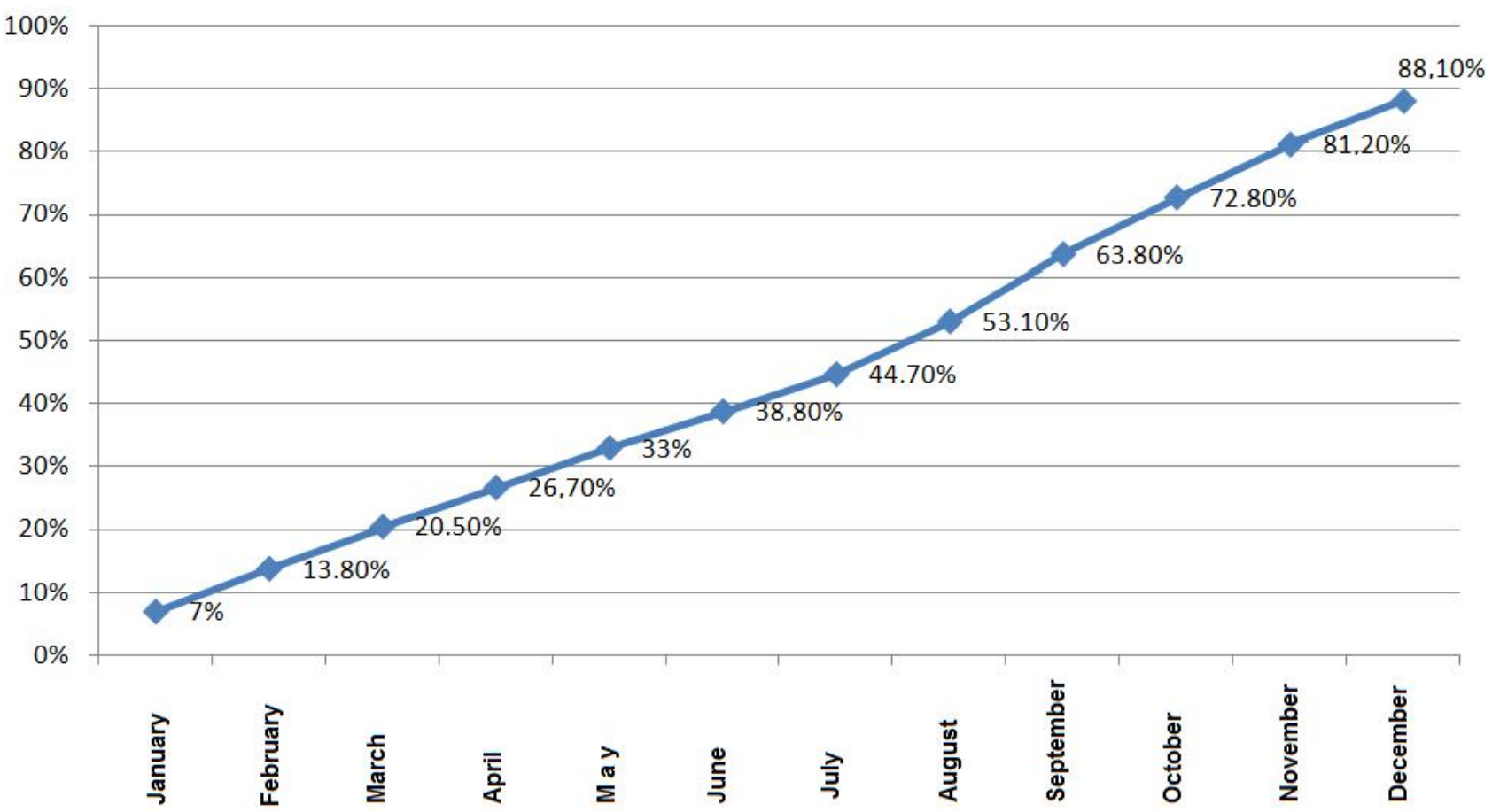

Figure 1a. Service Coverage Cumulative SDIDTK Puskesmas Mojo Year 2013

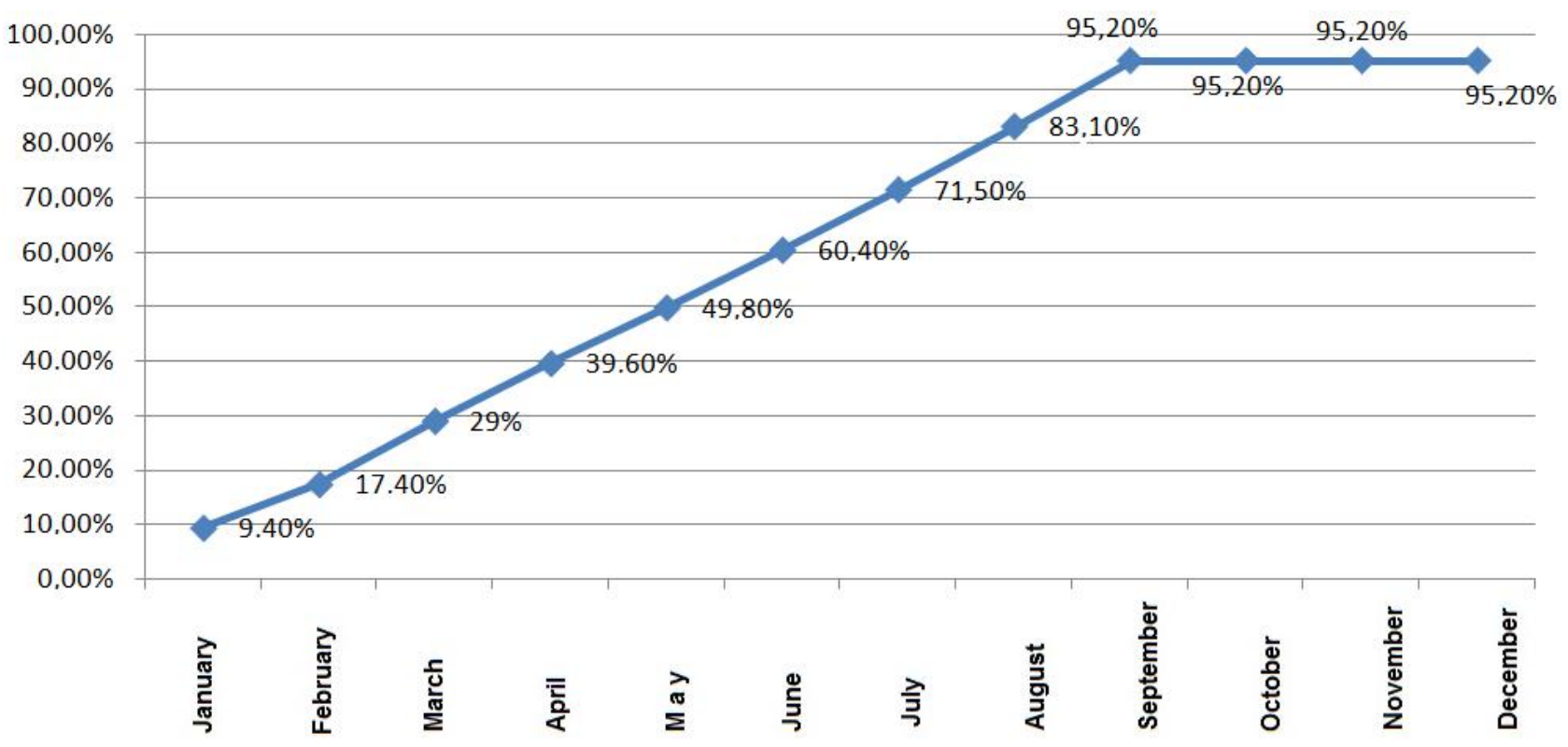

Figure 1b. Service Coverage Cumulative SDIDTK Puskesmas Mojo 2014

Table 1. Excerpts of answers of informant mothers, Posyandu cadres and early childhood teachers 
activities have never been done other than weighing, measuring height, head circumference, and distribution of food additives".

Informant 2 says:

"Developments examination activities will be conducted if there are reports from cadres on children who seem to experience delays, for example, has been in elementary school but cannot talk. Then we refer the children to the clinic and his development is examined by the midwives ".

Informant 3 says:

"Every six months our PAUD is visited by health center personnel to inquire whether a child is suspected of having a developmental delay. If yes, then development examination is carried out".

Informant 4 says:

"During my participation is this posyandu, my child has never been checked for his development".

\section{Results of NGT Delbeq Health Personnel on the Implementation of SDIDTK Program}

To find more information about the implementation of the program in Puskesmas Mojo SDIDTK this time, constraints and problems faced and looking for an alternative settlement of these problems, the researchers used a method NGT Delbecq. On October 7, 2014 researchers a facilitator in the decision-making process using methods NGT Delbecq is a discussion with members of the executive program in Puskesmas Mojo SDIDTK. The meeting was attended by two doctors, five midwives, and one nutritionist. There are three things that are discussed in this discussion. The first is the process of program implementation SDIDTK in Puskesmas Mojo during this, the second is constraints/ problems encountered so screening development cannot be done on each child, and the third is a solution that can be done so that screening the development can be done to every child each month in IHC.

SDIDTK program implementation has been done in Posyandu only give priority to growth monitoring that are with the weighing and measuring the height/length of the body, while monitoring developments with KPSP not done on every toddler in the IHC. If there are suspected cadres of children who have developmental delays, cadres will report to midwives and midwives will recommend that toddler's parents to come to the health center and then the child will be examined development using KPSP by midwives. If our child is delayed, then the child will be referred to Poli Growth in Hospital. Aside from reports of members, health center staff also disseminate this SDIDTK program to all kindergartens and early childhood in Puskesmas Mojo. Health worker regularly every six months will come to 33 kindergartens and 26 ECD in Puskesmas Mojo to get a report when there is a kindergarten teacher or early childhood suspect developmental delay in their students. Child suspected of having a developmental delay will then be checked by KPSP by health professionals (midwives). Healthy children who come to the health center for immunization suspected of having a developmental delay will be checked with KPSP by midwives.

All healthy children who come to the health center, all children enrolled in the IHC, all children of kindergarten and early childhood that has been visited by the program managers SDIDTK "considered" has been checked and compared with the number of infants who are targeted by the Department of Health. Figures reported this percentage as service coverage SDIDTK in Puskesmas Mojo. From the description can be inferred the existence of a problem that not all children and toddlers are routinely monitored its development. Only a child suspected of having a developmental delay is checked/screened using KPSP. The function of the actual development activity screening is to find out their developmental delays in children who have not seen delayed. If the screening activities performed on children who have seen developmental delay, then these activities can not be called as early detection activities.

There is a problem that not every child examined later development we discussed in the discussion of methods of NGT Delbecq session 2. From the discussion, it was found that the problem can occur for several reasons including the number of officers of limited SDIDTK program is not comparable with the number of children in Puskesmas Mojo. Activity monitoring progress using the screening tool KPSP within the competence of health workers (midwives) trained. Until now, Puskesmas Mojo only had 6 people midwife ( 2 people who have been trained) and only had one set of props as tools/complement Pre-Screening Questionnaire Development (KPSP). With these conditions, it is almost impossible to monitor progress on every toddler in Puskesmas Mojo regularly every month, given the number of children under five in Puskesmas Mojo target reached 5,393 in 2013 and 2,940 in 2014.

In addition to limited manpower, they also have the limited time. Work midwives not only implement the program SDIDTK, while for checking a child's development using KPSP should be done by trained health personnel (in Puskesmas Mojo there are two midwives who had been trained KPSP). Development checks using KPSP takes approximately 20-45 minutes (depending on the child's condition when examined whether cooperative or not). Puskesmas Mojo has only a screening tool in the form of KPSP form and one set 
of props to be used to screen thousands of children in the region Puskesmas Mojo.

In the discussion of methods of NGT Delbecq third session discussed several alternative solutions that could be done so that the activities of child development screening can be done in IHC on every toddler who monitored their growth. Some of the solutions proposed by members of the discussion group is to increase the number of health workers, add props, and examination of development must involve parents, teachers, and volunteers should be held developmental screening training for parents, teachers, and volunteers. So that we can involve parents, teachers and volunteers, the screening tools used should be made simpler. Recording and reporting system made simpler to facilitate the work of health workers, so that midwives are not only drained for administrative affairs. Of the six alternatives such solutions, solutions to increase the number of health professionals and props is difficult to be realized in the near future due to the availability of funds and policies related to procurement of resources. Thus the discussion forum decided on a solution involving the participation of parents, teachers, and health cadres in child development monitoring activities. Posyandu cadres can be empowered to help screen for developmental screening in conjunction with the current growth of Posyandu activities.

\section{DISCUSSION}

Glance attention to reports PWS (local Regional Monitoring) $\mathrm{MCH}$ (Maternal and Child Health) about the service coverage SDIDTK (Stimulation, Detection and Early Growth Interensi) in Puskesmas Mojo does not seem any problem. The last two years SDIDTK service coverage in Puskesmas Mojo already exceeded the target of East Java Provincial Health Office by $83 \%$, ie $88.1 \%$ in 2013 and $95.2 \%$ in 2014 . However, if we want to be involved in the activities of Posyandu, do not look any activity monitoring early childhood development, which exist only in the form of growth monitoring activities to measure activity in height and weigh toddlers. Based on interviews mothers, many mothers who claim their children were never examined its development.

According to the mother of cadres and early childhood teachers, only children suspected Posyandu cadres or teachers of early childhood developmental delay that will be investigated using KPSP development by puskesmas officers (midwife).

The results of the discussion using the NGT Delbecq with $\mathrm{PHC}$ health professionals to provide information that is actually not all children get the opportunity to examine progress regularly. Only a toddler who looked to have developmental delay has been checked using KPSP by health personnel. Figures $88.1 \%$ and $95.2 \%$ is actually a number of activities were just watching the growth screening height, weight and head circumference of children. While screening service development cannot be enjoyed by all children. This condition occurs because only health workers (doctors and nurses) who could use KPSP, while the number of health workers is not proportional to the number of infants. Property to support KPSP questionnaire owned by Puskesmas Mojo was only one set. In addition, the time used to check progress on the toddler only reach $20-45$ minutes.

Based on the recommendation of the Council on Children With Disabilities (2006), child development screening should be done on every child who visits the health-care activity for healthy children (every wellchild preventive care visit). In Indonesia, we have posyandu. If every child that comes into posyandu can be checked also its development, it would developmental disorders can be detected and intervention as early as possible.

Providing information about how to recognize child developmental delays and ways of stimulating the development of the parents/caregivers of children when they visit health facilities due to mild acute illness, may be one alternative to improve the screening coverage development (Ertem et al 2006). The importance of the integration of screening activities with the development of health service activities are already routinely done also described in the publication Earls and Hay (Earls \& Hay 2006), so that the development of screening can be done regularly and consistently as part of the first health service.

Problems developments screening done regularly on all children in posyandu not only occur in Puskesmas Mojo, Surabaya, but also occurs in Semarang (Maritalia 2009). Penelitian conducted by Setiyani (2012) also indicate that the poor performance of midwives in the use KPSP in PHC Magetan. SDIDTK in Posyandu activities are put on the table 5 system more early detection of irregularities of growth, while the screening and developmental stimulation never done specifically in IHC. Parents, cadres Posyandu, and early childhood teachers is actually a potential resource for helping make the program successful SDIDTK, but not optimized (Maritalia 2009). Lack of parental knowledge and Posyandu cadre about the stages of child development and the absence of tools that can be used by parents and volunteers to monitor the development of 
children causes them less vigilant in case of developmental delay in children.

\section{CONCLUSION}

Regular monitoring activities development in all infants allowed to do if we can empower Posyandu cadres to help health workers screened in an integrated development with Posyandu activities that have been routinely performed. In order to be empowered participation of cadres, needed a simple screening tool development that only a questionnaire to interview parents and without props such as ASQ (Ages and Stages Questionnaire), and PEDs (Parents Evaluation of Developmental Status). The use of props, in addition to requiring large funds also takes a lot of time in their utilization.

\section{ACKNOWLEDGMENT}

The authors would like to thank the Faculty of Medicine, University of Airlangga that has funded this study with RKAT fund, 2014.

\section{REFERENCES}

Council on Children With Disabilities, Section on Developmental Behavioral Pediatrics, Bright Futures Steering Committee, Medical Home Initiatives for Children With Special Needs Project Advisory Committee (2006). Identifying infants and young children with developmental disorders in the medical home: an algorithm for developmental surveillance and screening. Pediatrics 118, 405-420

Earls MF and Hay SS (2006). Setting the stage for success: implementation of developmental and behavioral screening and surveillance in primary care practice-The North Carolina Assuring Better Child health and Development (ABCD) Project. Pediatrics 118, e183-e188

Ertem IO, Atay G, Bingoler BE, Dogan DG, Bayhan A, Sarica D (2006). Promoting child development at sickchild visits: a controlled trial. Pediatrics 118, e124e131

Maritalia D (2009). Analisis pelaksanaan program Stimulasi Deteksi dan Intervensi Dini Tumbuh Kembang (SDIDTK) balita dan anak pra-sekolah di puskesmas kota Semarang tahun 2009. Thesis. Universitas Diponegoro, Semarang

Robson AL (2002). Critical/sensitive periods. In: Salkind JN (ed). Child Development, New York, Macmillan Referrence USA

Setiyani A (2012). Analisis faktor yang mempengaruhi kinerja bidan dalam pelaksanaan stimulasi, deteksi, dan intervensi dini tumbuh kembang di puskesmas kabupaten Magelang. Tesis. Universitas Diponegoro, Semarang

Suwarba IGN, Widodo DP, Handryastuti RAS (2008). Profil klinis dan etiologi pasien keterlambatan perkembangan global di rumah sakit Cipto Mangunkusumo Jakarta. Sari Pediatri 10, 255-261

Tjandrajani A, Dewanti A, Burhany AA, Widjaja JA (2012). Keluhan utama pada keterlambatan perkembangan umum di klinik khusus tumbuh kembang RSAB Harapan Kita. Sari Pediatri 13, 373377 